\title{
Giant meningioma in skull radiograph
}

\author{
Sami Khairy, ${ }^{1}$ Yasser Orz ${ }^{2}$
}

'Department of Neurosurgery, King Abdulaziz Medical City , King Abdullah International Medical Research Center , King Saud bin Abdulaziz University for Health Sciences, Ministry of National Guard Health Affairs,

Riyadh, Saudi Arabia

${ }^{2}$ Department of Neurosurgery in National Neuroscience Institute, King Fahad Medical City, Riyadh, Saudi Arabia

\section{Correspondence to} Dr Sami Khairy, drsami2009@hotmail.com

Accepted 6 September 2017

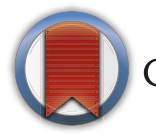

CrossMark

To cite: Khairy S, Orz Y. BMJ Case Rep Published Online First: [please include Day Month Year]. doi:10.1136/ bcr-2017-220833

\section{DESCRIPTION}

A 35-year-old woman presented to peripheral hospital with loss of consciousness, urine incontinence and behavioural changes. The family noticed her impulsiveness and irritability 2 months prior to her presentation to the emergency department. No history of fever, vomiting, trauma or seizures. She was transferred to our hospital and on arrival, she was confused, with normal cranial nerve examination and equally reactive pupils. She had marked weakness in right upper and lower limbs. Because intracranial lesion was suspected, a lateral skull X-ray and a CT scan were done which revealed a large left frontal extra-axial

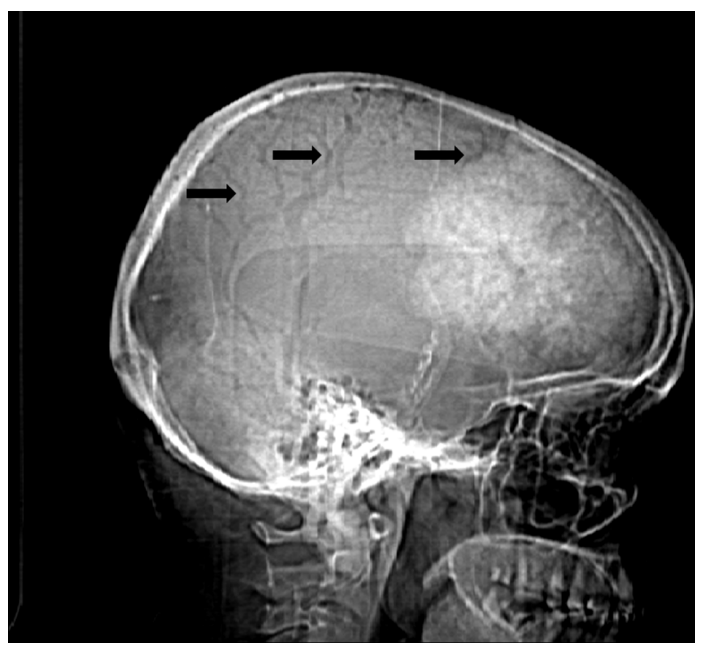

Figure 1 Lateral skull $\mathrm{X}$-ray showing large frontal hyperdense mass with evidence of enlarged meningeal artery grooves (arrows).

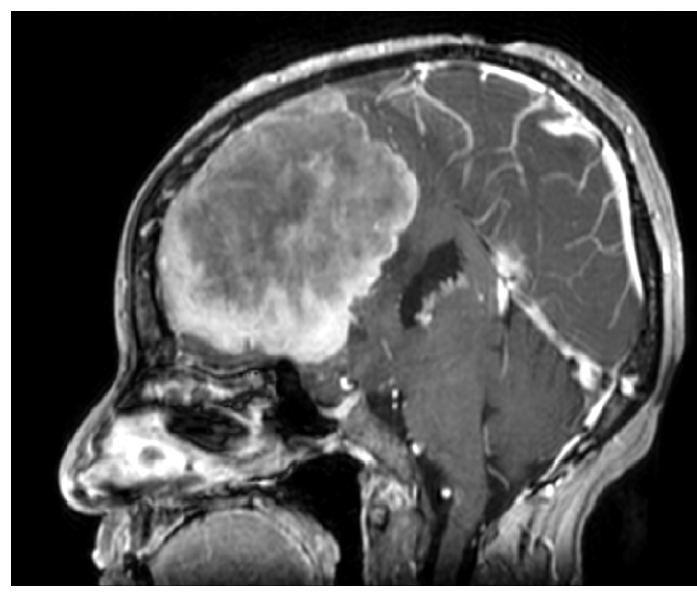

Figure 2 Sagittal T1 brain MRI with contrast showing huge extra-axial dural base enhance lesion with dural tail and compression on adjacent structures. calcified lesion with enlarged meningeal artery grooves (see figure 1 for the X-ray and figure 2 for the sagittal MRI). The patient underwent craniotomy and total removal of the meningioma with total weight of $347 \mathrm{~g}$ with pathological feature of psammomatous meningioma, WHO grade 1 (figure 3 ). ${ }^{1}$ She tolerated the procedure well and her neurological weakness as well as incontinence and behavioural changes improved gradually. Follow-up X-ray done the

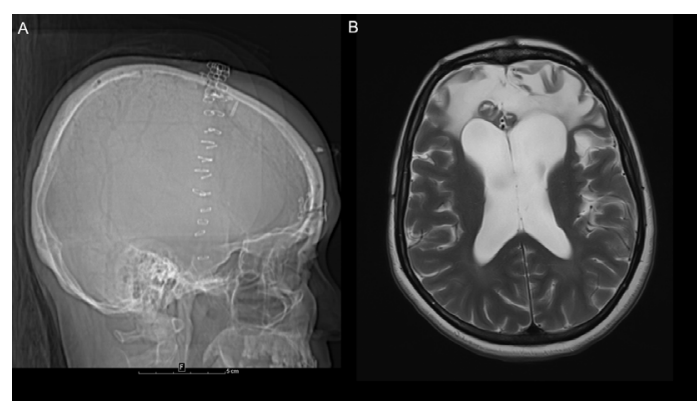

Figure 3 (A) Lateral skull X-ray postoperatively after total removal of the meningioma. (B) Axial T2 brain MRI showing total removal of the tumour with frontal encephalomalacia and mild compensating dilation of the anterior horn of lateral ventricle.

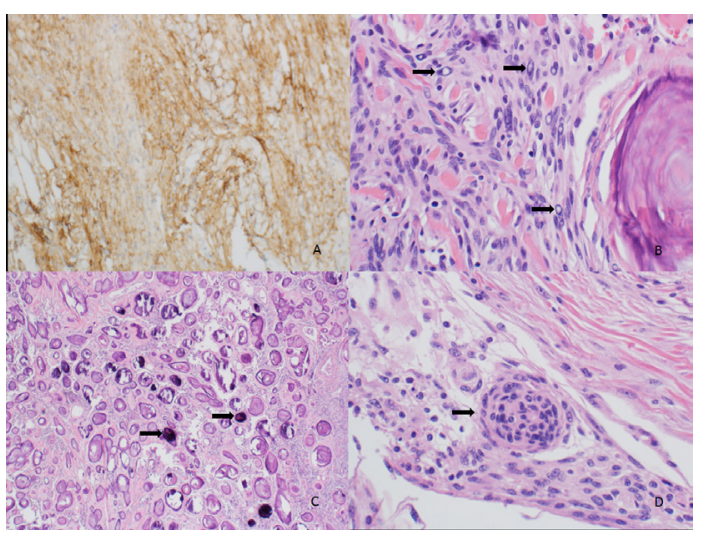

Figure 4 Pathology slide: (A) epithelial membrane antigen positive, (B) nuclear pseudoinclusion (arrows), (C) psammoma bodies (arrows) and (D) whorls (arrows).

Learning points

- Skull X-ray still has an important role in the diagnosis of cranial pathology.

- Slow development of symptoms always raises suspicion of tumour.

- Simple and quick investigation such as X-ray can direct the workup, save time and resources. 
next day postoperation and brain MRI done 6 months later (figure 4A,B) showed no residual or recurrence with frontal encephalomalacic changes. ${ }^{2}{ }^{3}$ Meningiomas are considered as the most common primary intracranial tumours.

Contributors SK and YO contribute in writing the article and collecting the images. Competing interests None declared.

Patient consent Obtained.

Provenance and peer review Not commissioned; externally peer reviewed. (c) BMJ Publishing Group Ltd (unless otherwise stated in the text of the article) 2017. All rights reserved. No commercial use is permitted unless otherwise expressly granted.

\section{REFERENCES}

1 Louis DN, Perry A, Reifenberger G, et al. The 2016 World Health Organization classification of tumors of the central nervous system: a summary. Acta Neuropathol 2016;131:803-20

2 Whittle IR, Smith C, Navoo P, et al. Meningiomas. Lancet 2004:363:1535-43.

3 Parizel PM, Carpentier K, Van Marck V, et al. Pneumosinus dilatans in anterior skull base meningiomas. Neuroradiology 2013;55:307-11.

Copyright 2017 BMJ Publishing Group. All rights reserved. For permission to reuse any of this content visit http://group.bmj.com/group/rights-licensing/permissions.

BMJ Case Report Fellows may re-use this article for personal use and teaching without any further permission.

Become a Fellow of BMJ Case Reports today and you can:

- Submit as many cases as you like

- Enjoy fast sympathetic peer review and rapid publication of accepted articles

Access all the published articles

- Re-use any of the published material for personal use and teaching without further permission

For information on Institutional Fellowships contact consortiasales@bmjgroup.com

Visit casereports.bmj.com for more articles like this and to become a Fellow 